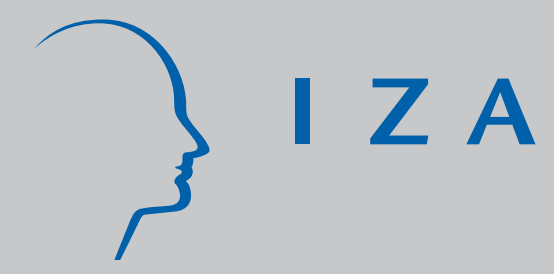

IZA DP No. 4115

Economic and Cultural Gaps among Foreign-born Minorities in Spain

Sara de la Rica

Francesc Ortega

April 2009 


\title{
Economic and Cultural Gaps among Foreign-born Minorities in Spain
}

\author{
Sara de la Rica \\ Universidad del Pais Vasco, \\ FEDEA, CReAM and IZA \\ Francesc Ortega \\ Universitat Pompeu Fabra, \\ INSIDE, CReAM and IZA
}
Discussion Paper No. 4115
April 2009

\author{
IZA \\ P.O. Box 7240 \\ 53072 Bonn \\ Germany \\ Phone: $+49-228-3894-0$ \\ Fax: +49-228-3894-180 \\ E-mail: iza@iza.org
}

\begin{abstract}
Any opinions expressed here are those of the author(s) and not those of IZA. Research published in this series may include views on policy, but the institute itself takes no institutional policy positions.

The Institute for the Study of Labor (IZA) in Bonn is a local and virtual international research center and a place of communication between science, politics and business. IZA is an independent nonprofit organization supported by Deutsche Post Foundation. The center is associated with the University of Bonn and offers a stimulating research environment through its international network, workshops and conferences, data service, project support, research visits and doctoral program. IZA engages in (i) original and internationally competitive research in all fields of labor economics, (ii) development of policy concepts, and (iii) dissemination of research results and concepts to the interested public.
\end{abstract}

IZA Discussion Papers often represent preliminary work and are circulated to encourage discussion. Citation of such a paper should account for its provisional character. A revised version may be available directly from the author. 
IZA Discussion Paper No. 4115

April 2009

\section{ABSTRACT \\ Economic and Cultural Gaps among Foreign-born Minorities in Spain}

This paper compares the economic and cultural gaps of the largest foreign-born ethnic minorities in Spain: Latinos, Eastern Europeans, Moroccans and individuals from Other Muslim countries. We focus on several outcomes: the gender education gap, early marriage, inter-ethnic marriage, fertility, female employment, command of Spanish, and social participation. Our results suggest that Latinos are the group with patterns of behavior closest to those of natives, followed by Eastern Europeans. In several dimensions, such as the marriage penalty for females, Moroccans and individuals from Other Muslim countries are the groups with larger gaps relative to natives. Our results also show large improvements in the educational attainment of younger Moroccan cohorts, which is an important determinant of the outcomes we have analyzed.

JEL Classification: J15, J61, F22

Keywords: immigration, cultural gaps, ethnicity, assimilation

Corresponding author:

Sara de la Rica

Universidad del País Vasco

Facultad de Ciencias Económicas y Empresariales

Avenida Lehendakari Aguirre, 83

48015 Bilbao

Spain

E-mail: sara.delarica@ehu.es

* The author acknowledges financial aid from the Spanish Ministry of Education and Science (SEC2006-10827). 


\section{Introduction}

Since the early 1990's immigration flows into Spain have been on the rise. In particular, the decade between 1998 and 2008 has been characterized by one of the largest immigration episodes in recent history among OECD countries. Over this period, the foreign-born share among the working age population in Spain has increased from below $3 \%$ to almost $15 \%$.

Aside from the large size of the inflows, Spain's immigration experience is characterized by the large heterogeneity of these inflows, in terms of origin. In 2008 the largest ethnic groups among the foreign-born population are Latinos, Eastern Europeans, and Moroccans. ${ }^{1}$ Interestingly, these groups differ substantially in their “cultural distance” vis-à-vis the Spanish society. Clearly, Latino immigrants face the smallest cultural gap since Spanish is the mother tongue for the large majority of the population and they are mostly Catholic. Arguably, Eastern Europeans are the second group regarding cultural distance vis-à-vis Spain. As shown later, the vast majority of Spain's immigrants from Eastern Europe are from Romania, a country with a Latinbased language (Romanian) and a traditionally Christian population (Eastern orthodox). Moreover, education levels are high, roughly at Spanish levels. Finally, Moroccans face the largest cultural gap with today's Spanish society among the three large minority groups. Morocco is an eminently Muslim country with low average education levels relative to Spain.

Recently, economists have turned their attention to the study of cultural transmission and its determinants (Bisin and Verdier 2000, Bisin, Topa and Verdier 2004). In this body of work, cultural transmission is defined as individuals' conscious efforts to maintain a certain social trait and pass it on to their offspring. In a way, this is the opposite of assimilation since in the absence of a costly action the group converges to the unconditional distribution of social traits in society. From this point of view, it is interesting to examine the cultural and economic gaps of ethnic foreign-born minorities that differ in the cultural distance to the norms in their host society. In particular, we

\footnotetext{
${ }^{1}$ The next section provides a detailed description of the sizes of these groups and their composition in terms of countries of origin. See Sandell (2008) for a detailed description of the ethnic composition of Spain's foreign-born population, as well as their geographical distribution within Spain.
} 
address the question of whether these gaps are increasing (or decreasing) in the cultural distance between natives and each minority ethnic group. Secondly, we examine the evolution of these gaps across cohorts, for each group.

We focus on the four main foreign-born ethnic groups: Latinos, Eastern Europeans, Moroccans, and individuals from Other Muslim countries. Specifically, we study the following dimensions of cultural gaps: the gender gap in educational attainment, fertility rates, early marriage, inter-ethnic marriage, female employment, command of Spanish, and social participation. Methodologically, we use regression analysis to provide a comparison across ethnic groups that accounts for differences in observables.

Our paper is related to a recent literature studying the cultural differences between Muslims and non-Muslis in western societies (Constant et al 2006, Manning and Roy 2007, and Bisin et al 2007). In particular, our work is closely related to Georgiadis and Manning (2008) who compare the cultural assimilation of Muslims to that of the other main ethnic minorities in the UK, along the same dimensions that we consider in this paper. These authors find substantial differences in the behavior of UK Muslims, conforming to a more traditional view of women and families. Their results also show rapid convergence toward "Western" norms of behavior. ${ }^{2}$ Our paper is also related to the demographic literature on the marriage patterns of the foreign-born population in Spain (Cortina et al 2008a, Cortina et al 2008b, Gonzalez-Ferrer and Cebolla-Boado 2008).

Overall our results suggest that Latinos - the group with the shortest cultural distance to Spanish social norms -, have assimilated the most. Moroccans and individuals from Other Muslim countries have assimilated the least, although the main differences seem to reflect differences in education levels.

Our results also suggest that years since migration and education are important determinants of economic and cultural gaps. Hence, it is important to control for differences in these two variables when comparing across ethnic groups. Furthermore,

\footnotetext{
${ }^{2}$ Interestingly, there appears to be no change in the degree of religiosity of Muslims in the UK, which suggests a more flexible interpretation of Islam than often perceived by outsiders.
} 
we find that education levels have risen rapidly for the younger cohorts of Moroccoborn immigrants, which suggests a narrowing of the gaps over time.

The structure of the paper is as follows. Section 2 introduces the datasets that we use. Section 3 provides an overview of Spain's recent immigration experience and a descriptive summary by ethnic group. Section 4 analyzes gender gaps in educational attainment. Section 5 is devoted to marriage and section 6 to fertility. Section 7 studies female employment. Section 8 and 9 explore the command of Spanish and social participation, respectively. Section 10 provides a comparison between the cultural assimilation of Muslims in Spain and in the UK. Section 11 concludes. All figures and tables can be found at the end of the paper.

\section{The Data}

Our two main data sources are the 2007 Labor Force Survey ("Encuesta sobre la Población Activa” or LFS) and the 2007 National Immigration Survey ("Encuesta Nacional de Inmigrantes” or NIS), both conducted by the Spanish Statistical institute.

The Spanish Labor Force Survey is well-known and standardized across all European countries. The new National Immigration Survey deserves some comments. This survey sampled the foreign-born population residing in Spain in 2007, with the goal of providing insights on migrants' experiences in transitioning from their home country into Spain, on their job history after arrival, and on their ties with the home country. The object of study were individuals born outside of Spain, who were at least 16 years old at the time of the survey, and had either been living in Spain for at least one year or had intention to do so. The total size of completed questionnaires is around 15,000. Correspondingly, our definition of immigrant is a foreign-born, adult individual that had been living in Spain for at least one year in 2007. In most of our analysis we will restrict to individuals age 16-60. When we report data on the native population we use the same age criterion. The next section provides a detailed overview of the foreignborn population in Spain. 


\section{Descriptive statistics}

This section describes the main ethnic groups in terms of their size, demographics, years since migration, and educational attainment.

\subsection{Country of origin and ethnicity}

According to Registry data, in 1998 the foreign-born population in Spain was small (2.95\% of the total population) and originated mainly in Morocco (16\%), France (12\%) and Germany (10\%). In the period 1998-2008, the foreign-born population has increased sharply and there has been a dramatic change in the composition of the inflows by country of origin. In 2008, the foreign-born share reached $13 \%$ of the total population and the share of the immigrant population originating in Morocco, France and Germany has fallen to $11 \%$, 2\%, and 3\%, respectively (2008 Registry). Let us now describe a bit more in detail the geographical origin of the foreign-born population in Spain in 2008 and its ethnic composition.

We start by examining the size of the immigrant population by geographical origin. Specifically, we use the 2007 NIS to classify the foreign-born population by country of birth. We also provide a comparison with the 2008 Registry data. The figures from the two sources are highly consistent.

As table 1 shows, according to the NIS almost $40 \%$ of the foreign-born population originated in the American continent, with Ecuador, Colombia and Argentina being the top three origin countries. Europe was the origin of 38\% of the foreign-born population, with Romania being the main country of origin, followed by the UK and France. According to the NIS, Romania accounted for $9.5 \%$ of the foreign-born population in Spain in 2007. As the 2008 Registry shows, the number of Romanians residing in Spain has increased sharply during 2007 reaching almost 14\% of the foreign-born population in 2008 and becoming the single main source country.

Among the remaining immigrants, $17 \%$ were born in African countries and slightly less than 5\% in Asia. The top three African countries of origin were Morocco (11.8\% of the 
foreign-born population), Algeria (1.2\%) and Senegal (0.7\%). The top three Asian countries of origin were China (1.2\%), the Philippines (1\%) and Pakistan (0.9\%).

Next, we turn to the definition of the ethnic groups that we shall use throughout our analysis. We define 4 groups: Latinos, Eastern Europeans, Moroccans and individuals from Other Muslim countries. Respectively, these groups account for 38.7\%, 16\%, $11.9 \%$, and $4.8 \%$ of the foreign-born population in 2007 (Table 2). The reasons to focus on these four groups are the following. Latinos and Eastern Europeans account for the lion's share of the immigration flows into Spain over the last decade. Traditionally, Morocco has been the main source immigration country for Spain, and still represents a very large share of the foreign-born population. In addition, the vast majority of Moroccans are Muslim, which makes it a very interesting group to study the immigration and assimilation experience of Muslim immigrants into Western societies. We have also included a fourth group, immigrants from other Muslim countries. We are particularly interested in comparing the behavior of this group to that of Moroccans. ${ }^{3}$

Table 2 reports the largest three countries of origin in each ethnic category and the share of each of those countries in the respective ethnic group. Latinos mainly originate from Ecuador (21\%), Colombia (17\%) and Argentina (13\%). By far, the main country of origin for Eastern Europe is Romania (60\% of the group), followed at a large distance by Bulgaria (14\%) and the Ukraine (9\%). The three main source countries in the group of Other Muslim countries are Algeria (24\%), Pakistan (18\%) and Senegal (14\%).

\subsection{Years since arrival}

Table 3 reports the distribution of individuals in each ethnic group by years since migration. On average, Moroccans arrived to Spain 14 years ago and immigrants from other Muslim countries 11 years ago. Latinos and, particularly, Eastern Europeans arrived to Spain much more recently. Respectively, 8.8 and 5.0 years ago on average.

\footnotetext{
${ }^{3}$ The NIS 2007 does not report religion at the individual level. We have defined a country to be Muslim if more than $80 \%$ of its population is Muslim in year 2008.
} 


\subsection{Age and gender}

This section describes the distribution of immigrants by age and gender for each ethnic group. Clearly, differences across groups in these distributions are likely to affect the rates of overall and inter-ethnic marriage, which we shall analyze later. Table 4 reports the age distributions, separately for men and women. We also include the analogous data for the native population to provide a basis for comparison.

Two features stand out. First, the age distribution is roughly similar across all groups. For instance, the share of individuals below age 30 is roughly $30 \%$ and the average age is 36 for immigrant males. Eastern Europeans are on average younger and Moroccans and individuals from Other Muslim countries tend to be older.

More dramatic differences appear when we look at the relative number of females in each age group, as illustrated by the third panel in Table 3. Consider women in the 1629 and 30-49 age groups. Among Latinos and Eastern Europeans, the share of women is roughly 50\%. However, it is only 35\% for Moroccans and below 25\% for Other Muslim countries. In other words, the supply of marriage-age women is much lower for the latter two ethnic groups. ${ }^{4}$

\subsection{Educational Attainment}

We now turn to the distribution by schooling of each ethnic group. We define three groups: individuals that at most completed primary education, individuals that completed secondary education, and individuals with completed tertiary education.

Table 5 reports the results, together with the education distribution of the native population. We restrict our sample to individuals age 25-50 to make the comparisons across groups more informative.

First, note that Moroccans have the lowest educational attainment. Average years of education are 7.4 for Moroccan men and 6.1 for Moroccan women. In contrast, Latinos

\footnotetext{
${ }^{4}$ Cortina et al (2008a) report differences in sex ratios by country, within ethnic group. For instance, the female share among Ecuadorians is particularly high.
} 
and Eastern Europeans have on average 10-11 years of schooling, only slightly below natives.

Next, we note that except for Moroccans, women are slightly more educated than men in all ethnic groups, including natives and immigrants from Other Muslim countries. The next section provides a more formal analysis of the gender gap in educational attainment.

\section{Gender Gaps in Education}

Public perception in many European countries, including Spain, is that Muslim minorities have markedly different attitudes regarding women's role in society. More generally, we provide a comparison of the gender gaps in education across ethnic groups and by birth cohort, which will be informative about the intensity of cultural assimilation for the different ethnic minorities.

Table 6 reports our estimates of the average gender gaps in years of education for different ethnic groups and birth cohorts using regression analysis. The dependent variable is years of education. The table reports the coefficient associated to a female dummy, which can be interpreted as the difference between the average years of education of women relative to men. We estimate a sLFSrate regression for each ethnic group and cohort. Standard errors are in parenthesis.

Table 6 reveals important differences in gender gaps in education across ethnic groups, as well as across birth cohorts. Consider first individuals in age bracket 31-40. Point estimates are positive - that is, women have higher education than men - for all groups except for Morocco. The values range from -2.46 years (Morocco) to 0.49 (Eastern Europe). For earlier (older) cohorts, point estimates are negative - women have lower education - for all groups, except for Other Muslim countries (not significant). Morocco displays the largest gender gap. Finally, among individuals younger than 30 we do not find a statistically significant gender gap for any group. Only Morocco displays a gender gap, although it is not statistically significant. 
In sum, for the largest cohort (age 31-40), we find evidence of a sizeable gender gap only for Morocco. For all minorities (including Moroccans) we find rapidly diminishing gender gaps across cohorts, possibly converging toward a situation with higher educational attainment for women.

\section{Marriage}

\subsection{Early marriage}

This section explores another interesting dimension along which behavior may vary across ethnic groups. We quantify cultural differences in marriage habits. Specifically, we focus on differences in the frequency of early marriage and inter-ethnic marriage.

We focus on females and say that a woman "married early" if she got married by age 25. Table 7 reports the distribution of early marriages by ethnicity, as well as predicted probabilities obtained from estimating linear probability models. ${ }^{5}$ Predicted probabilities are evaluated at each group's average characteristics. The first row of Table 7 reveals that $16 \%$ of Latino women married early. The figure is higher for Eastern European women (29\%), and much higher (62\%) among Moroccans and among women from Other Muslim countries (45\%). In comparison, only $2.9 \%$ of native women married early.

The second and third rows report the predicted probability of an early marriage with and without controlling for schooling, while controlling for age in both cases. The comparison is interesting because it is often argued that differences in the probability of early marriage simply reflect differences in education. As seen in the third row of Table 7, significant differences across ethnic groups still remain. Females from Muslim countries (in particular, Morocco) are much more likely to marry by age 25 than females from South and Central America (Latinas) or from Eastern Europe. Moreover, the result is not simply driven by lower educational attainment. We note that, relative to natives, early marriage is high for Latinas and Eastern European women as well.

\footnotetext{
${ }^{5}$ Our results do not vary much when we examine the distribution of early marriages for men, although males get married a bit older. We do not report the results for the sake of brevity.
} 


\subsection{Inter-ethnic marriage}

This section explores the performance of the different ethnic groups along another important dimension of cultural assimilation, namely, the frequency of inter-ethnic marriages. We focus on foreign-born individuals who are married and classify them according to the country of birth of their spouse. We define three categories: the two spouses were born in the same country, the spouse was born in Spain, or the spouse was born in a third country (that is, neither Spain nor one's own country). For comparison we also report on inter-marriage rates for natives, defined as marriage with a foreignborn individual. ${ }^{6}$

Table 8 reports our findings for each ethnic group and birth cohort. Panel 8A reports the distribution over the three types of marriage. Consider first age bracket 31-40, the largest cohort. We note first that marrying someone from a third country is very rare (below 5\% for all foreign-born minorities). Interestingly, we only detect this behavior in our data among Moroccans (1.82\%) and, especially, individuals from Other Muslim countries (4.40\%). Second, the fraction of inter-ethnic marriages with Spanish natives is highest among Latinos (33\% of all marriages), followed by Other Muslim countries (26\%), Moroccans (17\%), and Eastern Europeans (11\%). A proper interpretation of these figures requires accounting for differences in observables, such as years since migration, as well as taking into account differences in the age-gender distribution.

Panel 8B estimates the probability of an inter-ethnic marriage for each group, defined as the probability of marrying a Spain-native or an individual from a third country of origin on the sample of married individuals. The dependent variable takes the value of 1 if the individual is married either to a Spanish native or to someone from a third country (not Spain and not the individual's own country of birth). The reference group is married individuals younger than 31. A linear probability model is estimated, separately for each group. The coefficient reported under age $<31$ is the constant of the estimation and the rest of coefficients must be understood as the change in the probability of an inter-ethnic marriage with respect to the reference group. We control for years since

\footnotetext{
${ }^{6}$ Cortina et al (2008b) study how inter-marriage affects the probability of employment for married women, using Spanish data. They find that foreign-born women married to Spain-born natives have lower employment rates than those with foreign-born husbands. They also report that the type of partner does not have any effect on the probability of employment of native women.
} 
migration and age. First, our results show that the probability of an inter-ethnic marriage increases with time since migration for all groups. When we focus on individuals age 30 or younger, we find that $21 \%$ of married Latinos are in an inter-ethnic marriage. The comparable figures for Eastern Europeans and Moroccans are, respectively, 19\% and 16\%. A bit surprisingly, the highest probability of inter-ethnic marriages is for individuals from Other Muslim countries (36\%). In comparison, 22\% of married natives age 30 or younger had a foreign-born spouse.

It is worth pointing out a striking feature that appeared in Table 4 (panel 3). Namely, the fraction of women in marriage age is much lower among Moroccans and Other Muslim countries (roughly, by 20-30 percentage points for ages 16-29 and 30-49). As a result, there is a large excess demand for women in the "marriage market” for these groups. Thus while it may be the case that Muslim minorities have a stronger preference for intra-group marriage (or weaker), "market clearing” in the marriage market pushes men from these ethnic groups to marry outside their group. Our estimates in Table 8B support this interpretation for the group of Other Muslim countries, which features the highest probability of inter-ethnic marriage. In the case of Moroccans, we find a probability of inter-ethnic marriage that lies only slightly below that of Latinos and Eastern Europeans. This suggests there is a significant number of unmarried Moroccan women.

\section{Fertility}

This section examines fertility rates for each ethnic group. Following Georgiadis and Manning (2008), we focus on the sample of foreign-born women age 18-45. For each of them we compute the total number of children alive. Unlike in usual household surveys, our data include both children who are present in the household and children residing elsewhere (e.g. in the country of origin).

Table 9A reports the average number of children per woman for each of the ethnic groups considered in the study. Clearly, Moroccans and women from Other Muslim countries have relatively more children on average, respectively, 1.72 and 1.95 children per woman. In comparison, Latino and Eastern European women have on average 1.27 
and 0.97 children, respectively. The table also shows that the average age of women in the four ethnic groups is very similar.

We next provide a slightly more rigorous analysis. Specifically, we estimate a linear regression where the dependent variable is the total number of children on the sample of all foreign-born women in age range 18-45. On the right-hand side we include ethnic group dummies (with Latinos being our reference group) and a quadratic polynomial in age. We present two sets of estimates. In the first estimation we do not control for years of education but we do so in the second set of estimates. In the former case, the results confirm the findings suggested by the descriptive statistics. Namely, Moroccan women and women from Other Muslim countries have a significantly higher number of children than women from the other ethnic groups. Interestingly, the picture changes when we control for education levels. Now, Moroccan women have the same fertility as Latino women. In contrast, women from Other Muslim countries still display the highest fertility. In sum, controlling for age and education, Eastern European women have 0.2 fewer children than Latino and Moroccan women. Women from Other Muslim countries have 0.48 more children than Latinas.

\section{Female Employment}

We now turn to assimilation in the labor market. In particular, we are interested in comparing the employment rates of women across ethnic groups. It is traditionally believed that women from traditional Muslim societies are restricted in their ability to participate in the labor market.

Let us start by examining some descriptive statistics. Table $10 \mathrm{~A}$ reports the average employment rates among females in age bracket 25-59 for each ethnic group. Each row represents a different set of women. We consider all women, single women, married women, and married women with kids. When we compare the unconditional employment rates, we find striking differences. While almost 70 percent of Latino and Eastern European women work, only 35 and 42 percent of Moroccans and women from Other Muslim countries do. In comparison, 50\% of native women work. Interestingly, when we condition on being single, the employment rates of all four groups are very similar (and larger than for natives). However, when Moroccan women or women from 
Other Muslim countries get married or have children, their employment-population rates drop dramatically (30-40 percentage points). In contrast, the "penalty" of getting married or having children is much smaller for native women as well as for Latino and Eastern European women. Respectively, their employment-population rates only decrease by 5,10 and 4 percentage points.

Next, we estimate the conditional probability of being employed for each of the different ethnic groups and for each group of women, controlling for age and education. Table 10B displays the results. The estimates here confirm the findings suggested by the descriptive statistics above. Overall, Latino and Eastern European women are more likely to be employed. However, the marriage/children penalty is small for Latino and Eastern European women while very large for women born in traditionally Muslim countries (including Morocco). ${ }^{7}$

\section{Command of Spanish}

The purpose of this section is to examine the knowledge of Spanish of the different ethnic groups. Language difficulties may clearly prevent immigrants from an adequate integration in the host country. Given that among our ethnic groups there is a wide disparity in the distance between their original languages and Spanish, it is interesting to examine the outcomes for each group.

We classify the foreign-born population in three levels of fluency. The highest level corresponds to individuals that report Spanish as their first language. The second level contains individuals that report understanding and speaking Spanish. Finally, the lowest level of fluency corresponds to individuals that declare that they understand Spanish but do not speak it.

Table 11A reports our results. First, we consider all individuals, regardless of their year of arrival. Naturally, the vast majority of Latinos appear as native Spanish speakers (95\%). The other two groups with a significant proportion of native Spanish speakers are Morocco (9.55\%) and Other Muslim countries (7.66\%), reflecting the fact that some individuals were brought by their parents when they were very young and report

\footnotetext{
${ }^{7}$ It is worth noting that single Moroccan women have the highest employment-population rate.
} 
Spanish as their mother tongue. Eastern Europeans appear as the relatively less fluent group. However, even among this group the vast majority reports speaking and understanding the language. ${ }^{8}$

The second part of the Table reports on the command of Spanish of recent immigrants, defined as individuals that arrived one or two years prior to the survey. Clearly, the fraction of individuals that only understands Spanish increases for all groups, except for Latinos. The figures are 9.72\% for Eastern Europeans, 7.32\% for Moroccans and only $1.68 \%$ for individuals from Other Muslim countries. Overall, these descriptive statistics suggest that immigrants learn Spanish very quickly after arrival.

Next, we turn to a regression analysis to investigate the determinants of language fluency and to provide a more rigorous comparison across groups. In our analysis, we drop Latinos and individuals that report Spanish as their mother tongue. Our dependent variable is an indicator for whether an individual speaks and understands Spanish. The right-hand side variables include dummy variables for being Eastern European and being from Other Muslim countries. Thus, Morocco is the reference group in the regression. We also control for years since migration, age, and gender. We estimate a linear probability model.

Table $11 \mathrm{~B}$ reports the results. The intercept of the regression takes the value 0.79 , reflecting the very high proportion of individuals that speak and understand Spanish. Note that Eastern Europeans are significantly more likely to speak and understand Spanish than Moroccans (9.5 percentage points) when we control for age, years since migration and years of education. Instead, immigrants from Other Muslim countries are slightly less likely to have a good command of Spanish than Moroccans (4 percentage points). Turning to the controls, we find the expected signs. The level of command of Spanish is increasing in years since migration, increasing in education levels, but decreasing in age. It is worth noting that an extra year of education has a large effect on fluency. Likewise, one extra year since arrival appears to have an effect of the same

\footnotetext{
${ }^{8}$ The high level of command of Spanish across all groups is a bit surprising, and may partly reflect the design of the NIS. Recall that only individuals living in Spain for at least one year (or that intend to stay) were interviewed.
} 
size. Finally, our estimates suggest that women are less likely to be able to speak and understand Spanish.

In conclusion, the average level of Spanish is very high among all ethnic groups in our study, suggesting fast learning rates. However, we find significant differences across groups. Obviously, most Latinos are native Spanish speakers. More interestingly, we find that, after controlling for differences in observables, Eastern Europeans have better command of Spanish than Moroccans and individuals from Other Muslim countries. Our results seem very reasonable, once we recall that the vast majority of Eastern Europeans in Spain are from Romania. Thus, their mother tongue is also Latin-based, which makes learning Spanish relatively easy.

\section{Social Participation}

This section explores another dimension of assimilation, namely, the degree of participation in social activities. To address this issue we use two sets of questions posed to foreign-born individuals surveyed in the NIS. The first set asks about participation in clubs and associations specifically targeted to foreigners. More interesting for our purposes, the second set of questions is about participation in social activities that are not directly targeted to foreigners. In both cases, individuals are asked about participation in religious, cultural/educational activities, and sports clubs.

Table 12A presents some descriptive statistics. The first observation is that take-up rates are relatively low (below 5\% for all groups and activities). Sports clubs feature the highest participation while religious associations display the lowest. Secondly, Latinos seem to participate in activities not targeted to foreigners more often than other ethnic groups.

Table 12B provides a regression analysis. The dependent variable is an indicator for whether the individual participated in any type of association not directly targeted to foreigners. The rest of the specification is very similar to the one used in the previous section. On the right-hand side we include dummies for ethnic groups Eastern Europe, Morocco, and Other Muslim countries. The excluded category are Latinos. We control for age, gender, years since migration and years of education. 
Clearly, Latinos are the ethnic group that is more likely to participate in social activities not directly targeted to foreigners. Eastern Europeans are the least likely group to participate, after controlling for observables. Years since migration and education levels are conducive to larger social involvement, and women are less likely to participate.

\section{Comparison to the cultural assimilation of Muslims in the UK}

Georgiadis and Manning (2008) compare the cultural assimilation of the two largest Muslim communities in the UK (Pakistanis and Bangladeshis) to that of the other large ethnic minorities (Indian, Black Caribbean and Chinese). In our paper, we have focused on the main ethnic groups residing in Spain (Latinos, Eastern Europeans, Moroccans and individuals from Other Muslim countries). Interestingly, a large Muslim community is present both in Spain and in the UK. ${ }^{9}$ We next provide a comparison of the cultural assimilation of the Muslim community in the two countries. One must keep in mind that UK Muslims were mostly born in Pakistan and Bangladesh while Spain’s Muslims came mostly from Morocco.

Georgiadis and Manning (2008) find a relatively large education gender gap for the UK Muslim minority born outside of the UK. For those born after 1970, the gap is estimated to be 1.5-2 years. In the case of Spain's Muslims (Moroccans), we find a large gender gap (2.5 years) for individuals born between 1967 and 1977. However, this gap has virtually disappeared for individuals born after 1977.

Georgiadis and Manning (2008) report higher rates of early marriage (18-25 year olds) for the Muslim minority in the UK. This group is also characterized by a larger frequency of arranged marriages, and much lower frequencies of inter-ethnic marriages. Our findings suggest a similar picture for Spain’s Muslim community.

Georgiadis and Manning (2008) report significantly higher fertility rates for Muslim women. Our results also suggest that fertility rates are much higher among Moroccans.

\footnotetext{
${ }^{9}$ We suspect that the Eastern European community may be also sizeable in the UK. So it may be interesting to compare their assimilation process in the two countries as well.
} 
However, once we control for differences in educational attainment, the difference with the other ethnic groups disappears.

Georgiadis and Manning (2008) find that Muslim single women, without children, display similar employment rates to women in the other ethnic groups in the UK. However, the penalty associated to getting married or having children is quite steep. When these events take place, the employment rates of Muslim fall precipitously. Our results for Muslim women in Spain strongly suggest the same pattern.

In sum, both in the UK and in Spain there exist significant differences in the behavior of the average Muslim, relative to the average member of the other ethnic groups (more traditional). However, in both countries these differences seem to be vanishing. In the case of Spain, convergence in behavior appears mostly driven by the improvements in educational attainment of Moroccan females in the recent decades. ${ }^{10}$

\section{Conclusions}

Our aim in this paper is to examine the cultural and economic gaps of ethnic foreignborn minorities that differ in the cultural distance to the norms in their host society. In particular, we address the question of whether these gaps are increasing (or decreasing) in the cultural distance between natives and each minority ethnic group living in Spain. Secondly, we examine the evolution of these gaps across cohorts, for each group.

We focus on the four main foreign-born ethnic groups: Latinos, Eastern Europeans, Moroccans, and individuals from Other Muslim countries. Specifically, we study the following dimensions of cultural gaps: the gender gap in educational attainment, fertility rates, early marriage, inter-ethnic marriage, female employment, command of Spanish, and social participation.

\footnotetext{
${ }^{10}$ According to the NIS (2007), the average years of education for Moroccan immigrants age 30-49 was 6.9 years ( 5.4 for women). For the cohort age 16-29, the mean years of education were 7.3 (7.6 for women).
} 
Let us briefly summarize our findings. First of all, our descriptive analysis reveals large differences across ethnic groups in educational attainment, and in years since migration. Both variables are well known to be important determinants of assimilation. Moroccans arrived in Spain earlier and have substantially lower education levels. Eastern Europeans are the most recent arrivals and, together with Latinos, have schooling levels that are similar to those of natives. We also document the substantially lower share of young and middle-aged women in the Muslim foreign-born community, which clearly reduces their opportunities for intra-group marriage.

Secondly, we find that women are on average equally or more educated than men in all ethnic groups, except for Moroccans. For this group, the education gender gap for women in their 30s is roughly 2.5 years. For younger Moroccan women, the gap has virtually disappeared.

Third, we also find large differences in marriage patterns across ethnic groups. Our results suggest that Latinos have the lowest rates of early marriage (and overall marriage) while Moroccans and individuals from Other Muslim countries have the highest rates of early marriage (and overall marriage).

With respect to interethnic marriages, we find that the Latino group is the one with a higher fraction of marriages to Spanish natives (33\%), relative to the total number of marriages. This group is followed by Morocco and Other Muslim countries with, respectively, $17 \%$ and $26 \%$ of their married population having a Spain-born spouse. At the other end, only $11 \%$ of the married Eastern Europeans are married to Spanish natives. Our interpretation of these results are driven partly by cultural distance (which accounts for the high inter-ethnic marriage of Latinos) and partly by the imbalance in sex ratios faced by immigrants from Morocco and from Other Muslim countries, which limits the extent to which these individuals can marry within their ethnic group. In fact, only these two groups display significant rates of marriage to individuals from third countries of origin, that is, countries other than Spain or one's country of origin.

Fourth, we find that immigrants from Morocco and from Other Muslim countries have the highest fertility rates, while Eastern Europeans have the lowest. Our regression results show that low levels of education are largely responsible for the highest fertility 
of Moroccans. Controlling for education, Eastern Europeans still display the lowest fertility but Other Muslim countries becomes the highest-fertility group.

Fifth, we find that among single women (without children), employment rates are high and very similar for all ethnic groups. However, while marriage and children impose only a small employment penalty on Latino and Eastern European women, Muslim women's employment rates drop precipitously. The welfare implications are not obvious given that fertility rates are higher among women in these groups, which reduces the potential economic benefits of participating in the labor market.

Sixth, the command of Spanish is very high across all groups, although naturally the highest among Latinos. Over 90\% of immigrants of all ethnic groups that arrived in Spain recently (one or two years ago) understand and speak Spanish. However, there are significant differences across ethnic groups. Among non-Latinos, our regression analysis reveals that Eastern Europeans are 9 percentage points more likely to be fluent in Spanish than Moroccans, controlling for education and years since migration. At the same time, individuals from Other Muslim countries are 4 percentage points less likely than Moroccans.

Finally, our analysis of social participation reveals that Latinos are more likely to participated in clubs and associations non-targeted to foreigners, compared to all other groups.

Overall, our results suggest two conclusions. First, Latinos -the group with the shortest cultural distance to Spanish social norms- appear very similar to natives in most of the economic and cultural outcomes that we have examined. In contrast Moroccans and individuals from Other Muslim countries still display large gaps along several dimensions. Our results also suggest that years since migration and education are important determinants of economic and cultural gaps. Hence, it is important to control for differences in these two variables when comparing across ethnic groups.

Secondly, our findings on cultural and economic gaps for Moroccans and individuals from Other Muslim countries are similar to those reported in Georgiadis and Manning 
(2008) for Muslims in the UK. Both in Spain and in the UK, the gaps appear to be shrinking for the younger cohorts. 


\section{References}

- Bisin, A., Verdier, T., (2000). "Beyond the Melting Pot: Cultural Transmission, Marriage, and the Evolution of Ethnic and Religious Traits," Quarterly Journal of Economics, CXV(3), 955-988.

- Bisin, A., Topa, G., Verdier, T., (2004). "An Empirical Analysis of Religious Homogamy and Socialization in the U.S,” Journal of Political Economy, 112(3), 61564.

- Bisin, Alberto, Eleonora Patacchini, Thierry Verdier and Yves Zenou (2007) “Are Muslim Immigrants Different in Terms of Cultural Integration?”, CEPR Discussion Papers 6453.

- Chiswick, Barry R. (1980) "The Earnings of White and Coloured Male Immigrants in Britain”, Economica, 47, 81-87.

- Constant Amelie, and Klaus F. Zimmermann (2008) "Measuring Ethnic Identity and Its Impact on Economic Behavior”, forthcoming, Journal of the European Economic Association.

- Cortina, C., Esteve, A., Domingo, A. (2008a). "Marriage Patterns of the Foreign-Born Population in a New Country of Immigration: The Case of Spain." The International Migration Review.

- Cortina, C., Garcia, T., Esteve, A. (2008b). "Gender relations in intermarriage: lessons learned from the Spanish case." Mimeo.

- Georgiadis, Andreas, Alan Manning (2008) “Change and continuity among minority communities in Britain,” CEPR mimeo.

- Gonzalez-Ferrer, A., Cebolla-Boado, H., 2008. "Immigration in Spain: from handling new arrivals to integrating immigrants (in Spanish).” Centro de Estudios Politicos y Constitucionales. Cuadernos y Debates 184. Madrid.

- Manning, Alan and Sanchari Roy (2007) “Culture Clash or Culture Club? The Identity and Attitudes of Immigrants in Britain”, CEP Discussion Paper No. 790.

- Stewart, Mark B. (1983) "Racial Discrimination and Occupational Attainment in Britain”, Economic Journal, 93, 521-541.

- Sandell, R., 2008. “A Social Network Approach to Spanish Immigration: An Analysis of Immigration into Spain 1998-2006,” FEDEA working paper 2008-33. 
Tables

Table 1: Foreign-born population in Spain, by origin.

\begin{tabular}{||l|c|c|c|c||}
\hline Continent & $\begin{array}{c}\text { NIS 2007 } \\
\text { freq } \\
\text { thousands }\end{array}$ & $\begin{array}{c}\text { NIS 2007 } \\
\text { rel freq }\end{array}$ & $\begin{array}{c}\text { Registry 2008 } \\
\text { freq } \\
\text { thousands }\end{array}$ & $\begin{array}{c}\text { Registry 2008 } \\
\text { rel freq }\end{array}$ \\
\hline AMERICA & 1,779 & 39.5 & 1,703 & 36.0 \\
Ecuador & 370 & 8.2 & 383 & 8.1 \\
Colombia & 299 & 6.6 & 268 & 5.7 \\
Argentina & 232 & 5.1 & 180 & 3.8 \\
EUROPE & 1,718 & 38.1 & 2,018 & 42.7 \\
Rumania & 429 & 9.5 & 656 & 13.9 \\
UK & 269 & 6.0 & 315 & 6.7 \\
France & 203 & 4.5 & 88 & 1.9 \\
Alemania & 160 & 3.5 & 158 & 3.3 \\
Bulgaria & 100 & 2.2 & 140 & 3.0 \\
AFRICA & 761 & 16.9 & 772 & 16.3 \\
Morocco & 534 & 11.8 & 539 & 11.4 \\
Algeria & 53 & 1.2 & 47 & 1.0 \\
Senegal & 30 & 0.7 & 42 & 0.9 \\
ASIA & & & & \\
China & 207 & 4.6 & 230 & 4.9 \\
Philippines & 54 & 1.2 & 107 & 2.3 \\
Pakistan & 47 & 1.0 & 21 & 0.4 \\
Total Foreign-born & 49 & 0.9 & 44 & 0.9 \\
Total Spain & & 100 & 4,725 & 100 \\
\hline \hline & & & 46,064 & \\
\hline & & & & \\
\hline
\end{tabular}

Sources:

NIS 2007, Reference individuals. All Ages

Registry 2008 (January 1st) 
Table 2: Main ethnic groups in Spain in 2007.

\begin{tabular}{|c|c|c|}
\hline Ethnic group & $\begin{array}{c}\text { freq } \\
\text { thousands }\end{array}$ & $\begin{array}{c}\text { rel freq } \\
\%\end{array}$ \\
\hline LATI NOS & 1746 & 38.7 \\
\hline Ecuador & 370 & 0.21 \\
\hline Colombia & 299 & 0.17 \\
\hline Argentina & 232 & 0.13 \\
\hline EASTERN EUROPE & 720 & 16.0 \\
\hline Rumania & 429 & 0.60 \\
\hline Bulgaria & 100 & 0.14 \\
\hline Ukraine & 68 & 0.09 \\
\hline MOROCCANS & 537 & 11.9 \\
\hline OTHER MUSLI MS & 218 & 4.8 \\
\hline Algeria & 53 & 0.24 \\
\hline Pakistan & 39 & 0.18 \\
\hline Senegal & 30 & 0.14 \\
\hline REST & 1288 & 28.6 \\
\hline Total & 4509 & 100 \\
\hline
\end{tabular}

Note 1: Source is NIS 2007, Reference individuals. All ages.

Note 2: Relative frequency for ethnic groups is over total foreign-born population. For each individual country, relative frequency is over the respective ethnic group. 
Table 3: Years since migration, by ethnic group.

\begin{tabular}{||c|c|c|c|c||}
\hline YSM & Latinos & Eastern Europe & Morocco & Other Muslim \\
\hline 1 & 8.5 & 10.9 & 3.7 & 5.0 \\
2 & 7.8 & 9.3 & 5.4 & 4.9 \\
3 & 7.8 & 15.1 & 6.4 & 9.3 \\
4 & 10.0 & 14.5 & 7.6 & 10.3 \\
5 & 11.3 & 16.2 & 6.0 & 6.2 \\
6 & 14.2 & 12.1 & 8.9 & 7.4 \\
7 & 11.3 & 8.4 & 7.4 & 10.9 \\
8 & 6.8 & 5.1 & 5.0 & 6.3 \\
9 & 2.6 & 1.4 & 6.4 & 4.1 \\
10 & 1.5 & 0.5 & 2.7 & 1.7 \\
11 to 15 & 4.8 & 3.8 & 12.0 & 11.7 \\
over 15 & 13.6 & 2.8 & 28.5 & 22.2 \\
\hline All & 100 & 100 & 100 & 100 \\
mean & 8.8 & 5.1 & & 11.0 \\
\hline
\end{tabular}

Source: NIS 2007, Main sample (reference individuals age 16-60). 
Table 4: Age-gender distribution, by ethnic groups.

Source: NIS 2007, Main sample.

\begin{tabular}{||l|c|c|c|c|c||}
\hline $\begin{array}{l}\text { Only men } \\
\text { Age }\end{array}$ & Latinos & Eastern Europe & Morocco & Other Muslim & Natives \\
\hline & & & & & \\
16 to 29 & 31.9 & 32.0 & 30.0 & 26.4 & 20.9 \\
30 to 49 & 53.4 & 59.0 & 51.9 & 61.8 & 35.5 \\
50 to 64 & 10.8 & 8.2 & 13.1 & 8.6 & 22.9 \\
65 to 74 & 2.3 & 0.7 & 3.3 & 2.3 & 12.5 \\
over 75 & 1.6 & 0.2 & 1.8 & 0.9 & 8.26 \\
\hline & & & & & 100 \\
All & 100 & 100 & 100 & 36.9 & 46.77 \\
mean & 36.7 & 34.5 & 37.9 & 36.9 \\
\hline
\end{tabular}

\begin{tabular}{||l|c|c|c|c|c||}
\hline Only women & & & & & \\
Age & Latinos & Eastern Europe & Morocco & Other Muslim & Natives \\
\hline 16 to 29 & 29.9 & 39.7 & 30.3 & 25.4 & 18.6 \\
30 to 49 & 53.1 & 49.7 & 48.1 & 51.8 & 33.9 \\
50 to 64 & 12.5 & 10.1 & 12.3 & 12.1 & 22.3 \\
65 to 74 & 2.6 & 0.5 & 5.9 & 6.9 & 13.5 \\
over 75 & 2.0 & 0.1 & 3.3 & 3.7 & 11.7 \\
\hline & & & & & \\
All & 100 & 100 & 100 & 100 & 100 \\
mean & 37.7 & 34.1 & 39.1 & 40.7 & 48.94 \\
\hline
\end{tabular}

\begin{tabular}{||l|c|c|c|c|c||}
\hline $\begin{array}{l}\text { Fraction of } \\
\text { women } \\
\text { Age }\end{array}$ & Latinos & Eastern Europe & Morocco & Other Muslim & Natives \\
\hline & & & & & \\
16 to 29 & 52.6 & 54.0 & 36.5 & 25.5 & 49.1 \\
30 to 49 & 54.2 & 44.3 & 34.5 & 22.9 & 51.1 \\
50 to 64 & 57.7 & 53.9 & 34.8 & 33.1 & 51.6 \\
65 to 74 & 57.9 & 39.1 & 50.5 & 51.8 & 54.1 \\
over 75 & 58.9 & 29.2 & 51.9 & 60.2 & 60 \\
\hline
\end{tabular}


Table 5: Educational attainment of natives and immigrants.

Source: NIS for foreign-born and LFS for natives. Ages 25-50. Completed education.

\begin{tabular}{||l|c|c|c|c|c||}
\hline \multicolumn{1}{|c|}{ MEN } & Latinos & $\begin{array}{c}\text { Eastern } \\
\text { Europe }\end{array}$ & Morocco & Other Muslim & Natives \\
\hline & & & & & \\
Primary or less & 33.3 & 41.2 & 63.0 & 55.8 & 18.01 \\
Secondary & 45.2 & 48.5 & 26.6 & 29.8 & 56.35 \\
Tertiary & 21.5 & 10.4 & 10.4 & 14.5 & 25.64 \\
& & & & & \\
average years & 11.1 & 10.6 & 7.6 & 8.3 & 11.42 \\
\hline
\end{tabular}

\begin{tabular}{||l|c|c|c|c|c||}
\hline \hline \multicolumn{1}{|c|}{ WOMEN } & Latinos & $\begin{array}{c}\text { Eastern } \\
\text { Europe }\end{array}$ & Morocco & Other Muslim & Natives \\
\hline Primary or less & 31.0 & 30.9 & 77.5 & 58.3 & 18.72 \\
Secondary & 43.2 & 45.5 & 15.0 & 27.9 & 52.83 \\
Tertiary & 25.8 & 23.6 & 7.5 & 13.8 & 28.45 \\
& 11.1 & 11.2 & 5.7 & 8.5 & 11.61 \\
\hline
\end{tabular}


Table 6: Gender Gaps in Years of Education for different birth cohorts.

\begin{tabular}{|l|c|c|c|c|c|}
\hline Age & Latinos & $\begin{array}{c}\text { Eastern } \\
\text { Europe }\end{array}$ & Morocco & Other Muslim & Natives \\
\hline Less than 30 & 0.19 & $0.56^{* *}$ & -0.59 & 0.59 & $0.82^{* *}$ \\
& $(0.13)$ & $(0.20)$ & $(0.41)$ & $(0.79)$ & $(0.03)$ \\
\hline 31-40 years & 0.19 & $0.49^{* *}$ & $-2.46^{* *}$ & 0.21 & $0.54^{* *}$ \\
& $(0.14)$ & $(0.18)$ & $(0.45)$ & $(0.69)$ & $(0.04)$ \\
\hline 41-60 years & $-0.31^{* *}$ & -0.16 & $-0.79^{*}$ & 0.42 & $-0.35^{* *}$ \\
& $(0.16)$ & $(0.31)$ & $(0.45)$ & $(0.88)$ & $(0.03)$ \\
\hline
\end{tabular}

Data sources: NIS (2007) for foreign-born and LFS (2007) for natives.

Note: The dependent variable is years of completed education; the coefficient reported is the impact of female on years of education from a linear probability model. There is a separate estimation for each ethnic group and for each birth cohort. ${ }^{* *}$ significant at $1 \%,{ }^{*}$ significant at $10 \%$. All regressions control for age. Standard errors are in parenthesis.

Table 7: Early marriage.

Distribution and Predicted Probabilities by ethnicity. Females ages 16-25.

\begin{tabular}{|l|c|c|c|c|c|}
\hline & Latinos & $\begin{array}{c}\text { Eastern } \\
\text { Europe }\end{array}$ & Morocco & $\begin{array}{c}\text { Other } \\
\text { Muslim }\end{array}$ & Natives \\
\hline Proportion married & 0.16 & 0.29 & 0.62 & 0.45 & 0.03 \\
$(0.37)$ & $(0.45)$ & $(0.48)$ & $(0.51)$ & $(0.17)$ \\
\hline Predi. prob. married, & 0.17 & 0.29 & 0.60 & 0.46 & 0.03 \\
controls for age & $(0.12)$ & $(0.18)$ & $(0.23)$ & $(0.26)$ & $(0.03)$ \\
\hline $\begin{array}{l}\text { Pred. prob. married, } \\
\text { controls age and }\end{array}$ & 0.17 & 0.28 & 0.54 & 0.36 & 0.03 \\
education & $(0.13)$ & $(0.18)$ & $(0.21)$ & $(0.32)$ & $(0.04)$ \\
\hline N. observations & 442 & 237 & 125 & 20 & 8,892 \\
\hline
\end{tabular}

Data sources: NIS (2007) for Immigrants and LFS (2007) for Natives. Sample consists of all female between 16 and 25 years of age.

Notes: The first row computes the proportion of marriages. Standard deviation in brackets. In the second row, we compute the predicted probability of marriage evaluated at each ethnic group's average age. For this prediction, the dependent variable is an indicator of marriage among all female between 16 and 25 years of age. A linear probability model is estimated, and there is a separate estimation for each ethnic group. The third row computes the predicted probability of an early marriage, as before, but controlling for years of education. In rows 2 and 3, robust standard errors in brackets. ${ }^{* *}$ significant at $1 \%$, * significant at $10 \%$. 
Table 8: Inter-ethnic marriage.

Table 8A: Conditional means by ethnic group and birth cohort

\begin{tabular}{|c|c|c|c|c|c|}
\hline & Latinos & $\begin{array}{l}\text { Eastern } \\
\text { Europe }\end{array}$ & Morocco & $\begin{array}{l}\text { Other } \\
\text { Muslim }\end{array}$ & Natives \\
\hline $\begin{array}{l}\text { Age: Less than } 30 \\
\% \text { Married }\end{array}$ & 28 & 38 & 49 & 42 & 8.9 \\
\hline Spouse from & & & & & \\
\hline $\begin{array}{l}\text { Same country } \\
\text { Spain }\end{array}$ & $\begin{array}{l}68.6 \\
31.0\end{array}$ & $\begin{array}{l}80.6 \\
19.1\end{array}$ & $\begin{array}{c}90.9 \\
9.1\end{array}$ & $\begin{array}{l}73.9 \\
26.1\end{array}$ & 79.3 \\
\hline Third country & 0.0 & 0.3 & 0.0 & 0.0 & 21.9 \\
\hline $\begin{array}{l}\text { Age: } 31-40 \text { years } \\
\% \text { Married }\end{array}$ & 54 & 65 & 76 & 65 & 63.7 \\
\hline Spouse from & & & & & \\
\hline $\begin{array}{l}\text { Same country } \\
\text { Spain }\end{array}$ & $\begin{array}{l}66.7 \\
32.9\end{array}$ & $\begin{array}{l}88.6 \\
11.4\end{array}$ & $\begin{array}{l}80.9 \\
17.3\end{array}$ & $\begin{array}{l}69.2 \\
26.4\end{array}$ & 89.6 \\
\hline Third country & 0.0 & 0.0 & 1.8 & 4.4 & 10.4 \\
\hline $\begin{array}{l}\text { Age: } 41-60 \text { years } \\
\% \text { Married }\end{array}$ & 60 & 66 & 77 & 78 & 79.6 \\
\hline Spouse from & & & & & \\
\hline $\begin{array}{l}\text { Same country } \\
\text { Spain }\end{array}$ & $\begin{array}{l}55.0 \\
45.0\end{array}$ & $\begin{array}{l}87.9 \\
12.2\end{array}$ & $\begin{array}{l}61.7 \\
38.0\end{array}$ & $\begin{array}{l}54.0 \\
45.0\end{array}$ & 95.3 \\
\hline Third country & 0.0 & 0.0 & 0.3 & 0.0 & 4.7 \\
\hline
\end{tabular}

Sources: NIS (2007) for foreign-born and LFS (2007) for natives.

Notes: The sample is composed of all married individuals between 16 and 60 years. Third country means a country different from one's birth country and from Spain. For Natives, we have computed the percentage of all married individuals between 16 and 60 years married with a Spaniard (same country) or married to a foreign-born. 
Table 8B: Probability of inter-ethnic marriage.

Linear probability models.

\begin{tabular}{||l|c|c|c|c|c||}
\hline & Latinos & $\begin{array}{c}\text { Eastern } \\
\text { Europe }\end{array}$ & Morocco & $\begin{array}{c}\text { Other } \\
\text { Muslim }\end{array}$ & Natives \\
\hline Age: <31 years & $0.21^{* *}$ & $0.19^{* *}$ & $0.16^{* *}$ & $0.36^{* *}$ & $0.217^{* *}$ \\
& $(0.03)$ & $(0.02)$ & $(0.03)$ & $(0.06)$ & $(0.01)$ \\
Age: $31-40$ & $0.08^{*}$ & $-0.09^{* *}$ & 0.032 & 0.06 & $-0.113^{* *}$ \\
& $(0.04)$ & $(0.02)$ & $(0.04)$ & $(0.07)$ & $(0.01)$ \\
Age 41-60 & -0.06 & 0.05 & $-0.06^{* *}$ & -0.04 & $-0.169^{* *}$ \\
& $(0.04)$ & $(0.03)$ & $(0.04)$ & $(0.09)$ & $(0.01)$ \\
Years since mig. & $0.022^{* *}$ & $0.014^{* *}$ & $0.016^{* *}$ & $0.013^{* *}$ &.-- \\
& $(0.00)$ & $(0.00)$ & $(0.00)$ & $(0.00)$ & \\
observations & 2624 & 1181 & 1064 & 316 & 48707 \\
\hline \hline
\end{tabular}

Sources: NIS (2007). The sample is composed of all married individuals between 16 and 60 years.

Notes: For foreign-born, the dependent variable takes the value of 1 if the individual is married either to a Spanish native or to someone from a third country (not Spain and not the individual's own country of birth). For natives, the dependent variable equals one if married to a foreign-born. The reference group is married individuals younger than 31. A Linear Probability model is estimated, and there is a separate regression for each ethnic group. The coefficient reported under age $<31$ is the constant of the estimation and the rest of coefficients must be understood as the increase or decrease in the probability of an interethnic marriage with respect to the reference group. 
Table 9A

Average Number of Children by ethnic group

\begin{tabular}{|l|c|c|c|c|c|}
\hline & Latinos & $\begin{array}{c}\text { Eastern } \\
\text { Europe }\end{array}$ & Morocco & $\begin{array}{c}\text { Other } \\
\text { Muslim }\end{array}$ & $\begin{array}{c}\text { Average } \\
\text { Spain* }\end{array}$ \\
\hline Number of & 1.27 & 0.97 & 1.72 & 1.95 & 1.38 \\
children & $(1.19)$ & $(0.90)$ & $(1.60)$ & $(1.68)$ & \\
\hline Average Age & 32.9 & 31.28 & 32.29 & 32.7 & \\
Female & $(6.86)$ & $(6.72)$ & $(7.18)$ & $(6.47)$ & \\
\hline Observations & 2628 & 1063 & 548 & 122 & \\
\hline
\end{tabular}

Data source is NIS. The sample includes all females aged between 18 and 45 years of age. Standard Deviation in brackets. Data for Average Number of Children in Spain is taken from the Spanish Institute of Statistics (Basic Demographic Indicators - 2006, includes all native and immigrant women ).

Table 9B

Determinants of the Average Number of Children

\begin{tabular}{|l|l|l|}
\hline Controls & $\begin{array}{l}\text { Not Controlling } \\
\text { for Education }\end{array}$ & $\begin{array}{l}\text { Controlling } \\
\text { for Education }\end{array}$ \\
\hline Eastern Europe & $-0.18^{* *}$ & $-0.20^{* *}$ \\
& $(0.03)$ & $(0.03)$ \\
\hline Morocco & $0.51^{* *}$ & 0.02 \\
& $(0.06)$ & $(0.06)$ \\
\hline Other Muslim & $0.68^{* *}$ & $0.48^{* *}$ \\
& $(0.14)$ & $(0.12)$ \\
\hline Years of Education & - & $-0.08^{* *}$ \\
& & $(0.005)$ \\
\hline N. observations & 4361 & 4361 \\
\hline
\end{tabular}

Data source is NIS. The sample includes all females aged between 18 and 45 years of age. The dependent variable is number of children and there is a joint regression for all ethnic groups. Reference is Latinos. A linear regression is estimated. Each reported coefficient measures the difference in the average number of children between Latinos and the other ethnic origins. Age and age squared are also included in both regressions. Robust standard errors in brackets. ${ }^{* *}$ significant at $1 \%$, 
Table 10A

Female Employment Rates by Ethnic Group and for different demographic characteristics

\begin{tabular}{|c|c|c|c|c|c|}
\hline & Latinos & $\begin{array}{l}\text { Eastern } \\
\text { Europe }\end{array}$ & Morocco & $\begin{array}{l}\text { Other } \\
\text { Muslim }\end{array}$ & Natives \\
\hline All Women & $\begin{array}{c}0.70 \\
(0.45)\end{array}$ & $\begin{array}{c}0.69 \\
(0.46)\end{array}$ & $\begin{array}{c}0.35 \\
(0.47)\end{array}$ & $\begin{array}{c}0.42 \\
(0.49)\end{array}$ & $\begin{array}{c}0.499 \\
(0.50)\end{array}$ \\
\hline Single Women & $\begin{array}{c}0.76 \\
(0.43)\end{array}$ & $\begin{array}{c}0.71 \\
(0.45)\end{array}$ & $\begin{array}{c}0.65 \\
(0.48)\end{array}$ & $\begin{array}{c}0.68 \\
(0.47)\end{array}$ & $\begin{array}{c}0.527 \\
(0.499)\end{array}$ \\
\hline Married Women & $\begin{array}{c}0.65 \\
(0.47)\end{array}$ & $\begin{array}{c}0.67 \\
(0.47)\end{array}$ & $\begin{array}{c}0.26 \\
(0.44)\end{array}$ & $\begin{array}{c}0.32 \\
(0.47)\end{array}$ & $\begin{array}{c}0.478 \\
(0.498)\end{array}$ \\
\hline $\begin{array}{l}\text { Married Women } \\
\text { with children }\end{array}$ & $\begin{array}{c}0.65 \\
(0.48)\end{array}$ & $\begin{array}{c}0.66 \\
(0.47)\end{array}$ & $\begin{array}{c}0.24 \\
(0.43)\end{array}$ & $\begin{array}{c}0.31 \\
(0.47)\end{array}$ & $\begin{array}{c}0.438 \\
(0.499)\end{array}$ \\
\hline
\end{tabular}

Data Source is NIS for foreign-born and LFS for natives. The sample includes all females between aged 25 and 59 years.

Table 10B

Conditional Probability of Employment - All Women and for Different Demographic Characteristics

\begin{tabular}{|l|c|c|c|c|}
\hline & Latinos & $\begin{array}{c}\text { Eastern } \\
\text { Europe }\end{array}$ & Morocco & Other Muslim \\
\hline All Women & & & & \\
& 0.67 & 0.58 & 0.21 & 0.06 \\
& $(0.02)$ & $(0.05)$ & $(0.05)$ & $(0.09)$ \\
\hline Single Women & 0.675 & 0.61 & 0.74 & 0.29 \\
& $(0.04)$ & $(0.10)$ & $(0.13)$ & $(0.16)$ \\
\hline Married Women & 0.63 & 0.64 & 0.12 & 0.06 \\
& $(0.03)$ & $(0.06)$ & $(0.05)$ & $(0.08)$ \\
\hline Married Women with & 0.64 & 0.62 & 0.11 & 0.06 \\
children & $(0.04)$ & $(0.06)$ & $(0.05)$ & $(0.08)$ \\
\hline
\end{tabular}

Data Source is NIS. The sample includes all females between aged 25 and 59 years.

Notes: A linear probability model is estimated separately for each ethnic group and for each group of women. All regressions control for age (three age categories (less 35, 36-45 and older than 45 - less than 35 as reference) and for education (no education, primary, secondary and tertiary - reference: primary). Hence, the reported coefficients are the average employment rates for the reference female ( $<35$ with primary education) for each ethnic group and for each family situation. Robust Standard errors in brackets. 
Table 11: Fluency in Spanish by ethnic group.

Table 11A: Means, main sample NIS.

\begin{tabular}{||l|c|c|c|c||}
\hline & Latinos & Eastern Europe & Morocco & Other Muslim \\
\hline All individuals & & & & \\
Native-speaker & 94.9 & 0.5 & 9.6 & 7.7 \\
Speaks \& Understands & 4.9 & 96.7 & 87.3 & 89.0 \\
Only Understands & 0.2 & 2.9 & 3.1 & 3.3 \\
& 100.0 & 100.0 & 100.0 & 100.0 \\
Recent (ysm<3) & & & & \\
Native-speaker & 90.8 & 0.0 & 0.0 & 5.0 \\
Speaks \& Understands & 8.2 & 90.3 & 92.6 & 93.3 \\
Only Understands & 0.9 & 9.7 & 7.3 & 1.7 \\
& 100.0 & 100.0 & 100.0 & 100.0 \\
\hline
\end{tabular}

Table 11B - Probability of Speaking and Understanding Spanish

Sample: non-Latino, non-native speakers

Linear Probability Model

\begin{tabular}{||l|c||}
\hline \hline dep. var: & Speak \& Understand \\
\hline Constant & 0.791 \\
Eastern Europeans & {$[0.022]^{* * *}$} \\
Other Muslim Countries & 0.095 \\
& {$[0.013]^{* * *}$} \\
Years since Migration & -0.04 \\
Age & {$[0.016]^{* *}$} \\
& 0.013 \\
Years education & {$[0.001]^{* * *}$} \\
Female & -0.004 \\
& {$[0.001]^{* * *}$} \\
Observations & 0.013 \\
R-squared & {$[0.001]^{* * *}$} \\
\hline \hline
\end{tabular}


Table 12: Social participation in associations and clubs.

Sample: NIS, main sample.

Table 12A: Descriptive statistics

\begin{tabular}{||l|c|c|c|c||}
\hline & Latinos & Eastern Europe & Morocco & Other Muslim \\
\hline Targeted to foreigners & & & & \\
Religious (1) & 1.31 & 1.94 & 1.65 & 1.64 \\
Cultural and educational & 1.38 & 1.32 & 1.87 & 3.61 \\
Sports & 1.83 & 0.57 & 0.82 & 2.46 \\
Non-targeted & & & & \\
Religious (2) & 3.03 & 1.63 & 1.32 & 0.65 \\
Cultural and educational & 3.57 & 1.54 & 2.31 & 2.62 \\
Sports & 4.88 & 2.07 & 2.86 & 4.26 \\
& & & & 2.97 \\
Religious (1+2) & 4.34 & 3.57 & & 2.29 \\
\hline
\end{tabular}

Table 12B: Linear probability model.

Dependent variable: participation in either type of association, not targeted to foreigners.

\begin{tabular}{||l|c||}
\hline dep. var: & Participation \\
\hline Constant & 0.037 \\
Eastern Europeans & {$[0.014]^{* * *}$} \\
Moroccans & -0.045 \\
Other Muslim countries & {$[0.006]^{* * *}$} \\
& -0.036 \\
female & {$[0.008]^{* * *}$} \\
years since migration & -0.025 \\
& {$[0.012]^{* *}$} \\
age & -0.022 \\
& {$[0.006]^{* * *}$} \\
years of education & 0.002 \\
Observations & {$[0.000]^{* * *}$} \\
R-squared & 0 \\
\hline \hline
\end{tabular}

Omitted category is Latinos.

Robust standard errors in brackets

* significant at $10 \%$; ** significant at $5 \%$; *** significant at $1 \%$ 